\title{
Wildlife Responses to Vegetation Height Management in Cool-Season Grasslands
}

\author{
Brian E. Washburn ${ }^{1}$ and Thomas W. Seamans ${ }^{2}$ \\ Authors are ${ }^{1}$ Research Wildlife Biologist and ${ }^{2}$ Wildlife Biologist, US Department of Agriculture, Wildlife Services, National Wildlife Research Center, \\ 6100 Columbus Avenue, Sandusky, OH 44870.
}

\begin{abstract}
Herbaceous vegetation comprises the main habitat type in cool-seasons grasslands and can be managed by various methods. We compared changes in plant communities and bird and mammal use of grasslands that were not managed, managed by mechanical methods (mowing), or managed by chemical methods (plant growth regulator). This 1-year study was conducted from May through October 2003 in Erie County, Ohio. Twelve circular 1.5 ha plots were established: 4 were not managed, 4 were mowed to maintain vegetation height between $9-15 \mathrm{~cm}$, and 4 were sprayed with a plant growth regulator and mowed when vegetation exceeded $15 \mathrm{~cm}$. We monitored vegetation growth, measured plant community composition, and observed all plots for wildlife activity each week. Vegetation in unmanaged plots was taller and denser $(P<0.001)$ than vegetation in mowed and growth regulator plots. Plant community characteristics differed among study plots $(P<0.001)$; managed plots had higher grass cover and lower woody cover than unmanaged plots. We observed more $(P<0.001)$ total birds per 5 -minute survey in unmanaged than mowed or growth regulator plots. We observed more $(P<0.001)$ white-tailed deer $(O d o c o i l e u s$ virginianus) in mowed plots than either control or growth regulator plots. We captured 13 small mammals in unmanaged plots and no small mammals in managed plots. Applying the plant growth regulator was not a cost-effective alternative to mowing for managing vegetation height in our study. Vegetation height management practices altered plant communities and animal use of grassland areas and thus might be useful for accomplishing species-specific habitat management objectives.
\end{abstract}

\section{Resumen}

La vegetación herbácea comprende el principal tipo de hábitat en los pastizales de estación fría y pueden ser manejados con varios métodos. Comparamos los cambios en las comunidades de vegetales y el uso de las aves y mamíferos de los pastizales sin manejo, manejados por métodos mecánicos (siega) o manejados con métodos químicos (reguladores de crecimiento vegetal). Este estudio de un año se condujo de mayo a octubre de 2003 en el condado Erie, Ohio. Se establecieron 12 parcelas circulares de 1.5 ha: 4 no recibieron manejo, 4 fueron segadas para mantener la vegetación a una altura entre 9-15 cm, y 4 fueron asperjadas con un regulador de crecimiento vegetal y segada cuando la vegetación excedió $15 \mathrm{~cm}$. Semanalmente, monitoreamos el crecimiento vegetal, medimos la composición de la comunidad vegetal y observamos todas las parcelas para registrar la actividad de la fauna silvestre. La vegetación de las parcelas sin manejo fue más alta y densa $(P<0.001)$ que la de las parcelas segadas y las que recibieron el regulador de crecimiento vegetal. Las características de la comunidad vegetal difirieron entre las parcelas de estudio $(P<0.001)$; las parcelas con manejo tuvieron mayor cobertura de zacates y menor cobertura de plantas leñosas que las parcelas sin manejo. En los periodos de reconocimiento de 5 minutos, observamos más $(P<$ $0.001)$ aves las parcelas sin manejo que en las segadas o tratadas con el regulador de crecimiento. Observamos más $(P<0.001)$ venado cola blanca (Odocoileus virginianus) en las parcelas segadas que en las parcelas control o con regulador de crecimiento vegetal. Capturamos 13 pequeños mamíferos en las parcelas sin manejo y ninguno en las parcelas manejadas. En nuestro estudio, la aplicación del regulador de crecimiento vegetal, en relación a la siega, no fue una alternativa efectiva en términos de costos para manejar la altura de la vegetación. Las prácticas de manejo de la altura de la vegetación alteraron las comunidades vegetales y el uso de las áreas de pastizal por los animales; pero pudieran ser útiles para lograr objetivos de manejo de hábitat de especies específicas.

Key Words: grassland birds, growth regulator, mowing, white-tailed deer

\section{INTRODUCTION}

Grassland habitats in the United States, regardless of the ecotype, are often managed in a prescribed way (e.g., mowing,

Research was funded in part by the Federal Aviation Administration, the US Department of Agriculture, and the BASF Corporation.

Correspondence: Brian Washburn, USDA Wildlife Services National Wildlife Research Center, 6100 Columbus Avenue, Sandusky, OH 44870. Email: brian.e.washburn@aphis.usda.gov

Manuscript received 3 August 2006; manuscript accepted 27 February 2007. prescribed burning, grazing) to maintain the integrity of the physical characteristics desired for that habitat type. These management methods can be applied to hayfields, pastures, rangelands, airfields, old-fields, and other human-altered systems (Bollinger 1995; Norment 2002). Eastern grassland habitats are typically dominated by introduced cool-season grasses (e.g., tall fescue [Lolium arundinaceum \{Schreb.\} S. J. Darbyshire], timothy [Phleum pratense L.]), cool-season forbs and legumes (e.g., clovers [Trifolium spp. L.]), and few native plants (Vickery and Dunwiddie 1997; Norment 2002). These 
grassland areas are maintained in an early successional stage through disturbance, typically by a method to maintain vegetation at a desired height.

Mechanical mowing is the most widely used tool for managing vegetation height in humid grassland areas. However, mowing grassland areas during the breeding season can reduce reproductive success of grassland birds (Frawley and Best 1991; Bollinger 1995). Other tools, such as herbicides and plant growth regulators, might be useful for managing vegetation growth and structural characteristics (Morré 1993; Reynolds et al. 1993). Using selective herbicides might allow land managers to alter vegetation structure and composition in cool-season grasslands by removing or favoring (e.g., by removing competition) certain types of plants (Washburn et al. 2002).

Our study objectives were: 1 ) to compare the effectiveness of management techniques for managing vegetation height and altering plant community characteristics and 2) to compare bird and mammal use of cool-season grasslands that were not managed, managed by mechanical methods (mowing), or managed by chemical methods (plant growth regulator).

\section{MATERIAL AND METHODS}

\section{Study Site}

The study was conducted from May 2003 through October 2003 at the National Aeronautics and Space Administration's Plum Brook Station (PBS), Erie County, Ohio (lat $41^{\circ} 37^{\prime} \mathrm{N}$, long $82^{\circ} 66^{\prime} \mathrm{W}$; elevation $\left.198 \mathrm{~m}\right)$. Mean annual precipitation is $863 \mathrm{~mm} \cdot \mathrm{y}^{-1}$ and the average daily temperature during summer is $22.2^{\circ} \mathrm{C}$ (Robbins et al. 2002). Habitat within PBS consists of dogwood (Cornus spp. L., 39\%), grasslands (31\%), open woodlands $(15 \%)$, mixed hardwood forests $(11 \%)$, and roads and buildings (4\%) (Rose and Harder 1985).

In May 1999, 8 circular 1.5-ha plots were established by clearing and then mowed 2-4 times a month during the growing season in 1999-2002 as part of a study examining effects of vegetation height on wildlife use of grassland areas (Seamans et al. 2007). For this study, 4 of these plots were randomly selected to be mowed with the remaining 4 to be treated with a plant growth regulator (herbicide mixture) and mowed as needed. In addition, 4 additional plots in unmanaged herbaceous fields were selected as control plots. Plant communities in the plots consisted of a variety of grasses, forbs, and legumes.

\section{Vegetation Height Management}

At the start of the study, the 4 mowed and 4 growth regulator plots were mowed to a height of $9 \mathrm{~cm}$. Throughout the study, when the mean maximum vegetation height of $15 \mathrm{~cm}$ was exceeded in a mowed or growth regulator plot we mowed the plot to a height of $9 \mathrm{~cm}$.

A plant growth regulator (herbicide) mixture was applied to the regulator plots twice, on 14 May 2003 and 28 July 2003. The plant growth regulator mixture consisted of imazapic at $0.05 \mathrm{~kg}$ active ingredient (ai) $\cdot \mathrm{ha}^{-1}$ (Plateau herbicide, BASF Corp, Research Triangle, NC), dicamba at $0.23 \mathrm{~kg}$ ai $\cdot \mathrm{ha}^{-1}$ plus diflufenzopyr at $0.08 \mathrm{~kg}$ ai $\cdot \mathrm{ha}^{-1}$ (Overdrive herbicide, BASF Corp, Research Triangle, NC), and non-ionic surfactant at $2.3 \mathrm{~L} \cdot \mathrm{ha}^{-1}$. The sprayed plots were not mowed during the week following plant growth regulator application.

\section{Vegetation Measurements}

Plant community characteristics in all plots were measured weekly from 5 May 2003 to 14 October 2003. Each week, 10 sample points were randomly selected in each of the 12 circular 1.5-ha plots. At each sample point, we measured the maximum vegetation height by placing $2,1-\mathrm{m}$ sticks vertically $1.5 \mathrm{~m}$ apart with a string connecting the sticks. We adjusted the height of the string parallel to the top of the tallest plant under the string and recorded the distance from the string to the ground $(\mathrm{cm})$. We also measured two visual obstruction readings (VOR) at each sample point (Robel et al. 1970). Plant cover by species group (e.g., grass) was sampled at 6 set points along the $1.5-\mathrm{m}$ string used to measure vegetation height. The plant immediately below each sample point was classified into 1 of 9 species groups.

\section{Animal Observations}

Birds. Bird observations were conducted 2 days per week from 8 May 2003 to 16 October 2003 starting at randomly chosen plots and times from sunrise to sunset. We observed each circular 1.5-ha plot from a fixed point within $30 \mathrm{~m}$ of the plot for 5 minutes once each day. The number of birds observed on the ground or on a plant within the plot, flying and feeding over the plot, or flying over the plot was recorded by species and activity.

Mammals. We estimated white-tailed deer (Odocoileus virginianus) use of the circular 1.5 -ha plots by conducting 2 sets of 3-minute observations (i.e., surveys) once every 2 weeks from 15 May 2003 to 16 October 2003. We started the first survey 30 minutes before sunset and used binoculars to count deer in or within $1 \mathrm{~m}$ of each plot. We started the second survey 30 minutes after sunset and used a Forward-looking Infrared (FLIR) unit (PalmIR 250, Raytheon Commercial Infrared, Dallas, TX) to count deer.

Small mammal abundance was quantified by snap trapping all circular 1.5-ha plots for 3 nights in April of 2003 and also for 2 nights in October of 2003. A $50 \times 100 \mathrm{~m}$ trapping grid centered in each plot was used with modified rat traps placed at $10-\mathrm{m}$ intervals (50 traps $\left.\cdot \operatorname{plot}^{-1}\right)$. Capture rate was defined as the number of animals caught 100 adjusted trap nights ${ }^{-1}$ (Nelson and Clark 1973). The National Wildlife Research Center Institutional Animal Care and Use Committee approved procedures involving birds and mammals (QA-1038).

\section{Statistical Analyses}

Vegetation data were non-normally distributed and could not be transformed satisfactorily. We used Kruskal-Wallis tests (Zar 1996) to compare plant community characteristics among vegetation management treatments. The percentage of times mowed and growth regulator plots were mowed was compared using a comparison of proportions test (Zar 1996). We wanted to consider only birds actually associated with (e.g., using) the plots and thus removed birds with the "flying" activity codes from the data prior to analyses. The bird and deer observation data were not normally distributed and could not be transformed satisfactorily. Therefore, we compared bird and 
Table 1. Plant community composition of unmanaged, mowed, and growth regulator plots in Erie County, Ohio, May through October 2003.

\begin{tabular}{|c|c|c|c|}
\hline \multirow[b]{2}{*}{ Treatment } & \multicolumn{3}{|c|}{ Percent cover $( \pm \mathrm{SE})$} \\
\hline & Grass (\%) & Forb and legume (\%) & Woody (\%) \\
\hline \multicolumn{4}{|l|}{ PRE (5-12 May) ${ }^{1}$} \\
\hline Unmanaged & $64.4 \pm 5.9 \mathrm{~A}^{2}$ & $30.8 \pm 5.1 \mathrm{~A}$ & $3.9 \pm 1.3 \mathrm{~A}$ \\
\hline Mowed & $68.0 \pm 4.9 \mathrm{~A}$ & $30.6 \pm 5.3 \mathrm{~A}$ & $1.1 \pm 0.4 \mathrm{~A}$ \\
\hline Regulator & $63.0 \pm 8.0 \mathrm{~A}$ & $32.9 \pm 7.4 \mathrm{~A}$ & $2.0 \pm 0.7 \mathrm{~A}$ \\
\hline \multicolumn{4}{|c|}{ POST 1 (14-21 July) ${ }^{3}$} \\
\hline Unmanaged & $30.0 \pm 6.6 \mathrm{~A}$ & $56.5 \pm 7.7 \mathrm{~A}$ & $12.0 \pm 5.4 \mathrm{~A}$ \\
\hline Mowed & $65.0 \pm 6.6 \mathrm{~B}$ & $33.4 \pm 7.2 \mathrm{AB}$ & $1.3 \pm 0.5 \mathrm{~A}$ \\
\hline Regulator & $75.6 \pm 5.9 B$ & $16.8 \pm 4.7 \mathrm{~B}$ & $4.0 \pm 1.1 \mathrm{~A}$ \\
\hline \multicolumn{4}{|c|}{ POST 2 (6-14 0ct $)^{4}$} \\
\hline Unmanaged & $57.6 \pm 7.9 \mathrm{~A}$ & $26.9 \pm 4.0 \mathrm{~A}$ & $15.3 \pm 5.1 \mathrm{~A}$ \\
\hline Mowed & $82.8 \pm 2.7 \mathrm{AB}$ & $16.6 \pm 2.9 \mathrm{~A}$ & $0.6 \pm 0.4 \mathrm{~B}$ \\
\hline Regulator & $91.9 \pm 2.0 \mathrm{~B}$ & $3.5 \pm 0.9 \mathrm{~B}$ & $0.3 \pm 0.3 \mathrm{~B}$ \\
\hline
\end{tabular}

\footnotetext{
${ }^{1}$ The PRE period was prior to the application of plant growth regulator mixture. Vegetation was mowed to a height of $9 \mathrm{~cm}$ in the mowed and regulator plots.

${ }^{2}$ Means within the same column within a period with the same letter are not different $(P>0.05)$ according to a Kruskal-Wallis test.

${ }^{3}$ The POST 1 period was 9 and 10 weeks after the first application of the plant growth regulator mixture to the regulator plots.

${ }^{4}$ The POST 2 period was 9 and 10 weeks after the second application of the plant growth regulator mixture to the regulator plots.
}

deer use among treatments using Kruskal-Wallis tests (Zar 1996). We considered differences significant at $P \leq 0.05$. Data are presented as mean \pm 1 standard error.

\section{RESULTS}

\section{Plant Communities}

Mean maximum vegetation height differed $(P<0.001)$ among the managed and unmanaged plots. Vegetation in the unmanaged plots $(60.5 \pm 0.8 \mathrm{~cm})$ was taller than vegetation in the mowed $(17.3 \pm 0.1 \mathrm{~cm})$ and growth regulator plots $(16.9 \pm$ $0.2 \mathrm{~cm})$. Similarly, the mean VOR in unmanaged plots $(27.8 \pm$ $0.5 \mathrm{~cm})$ was greater $(P<0.001)$ than the similar mowed $(5.7 \pm$ $0.1 \mathrm{~cm})$ and growth regulator $(5.3 \pm 0.1 \mathrm{~cm})$ plots. We found no difference $(P=0.30)$ in the percentage of times that mowed $(77.6 \pm 5.0 \%)$ or growth regulator $(67.1 \pm 7.9 \%)$ plots were mowed.

Vegetation height management practices altered the plant community composition of mowed and growth regulator plots compared to the unmanaged plots (Table 1). Mowed and growth regulator plots had more grass $(P \leq 0.001)$ than unmanaged plots. Forbs and legumes were reduced $(P \leq 0.001)$ in the growth regulator plots following 1 and 2 applications of the growth regulator mixture. Unmanaged plots contained more woody plants than either mowed or growth regulator plots (Table 1).

\section{Animal Responses}

Birds. We observed more $(P<0.001)$ birds per 5 -minute survey on the ground and perched on vegetation in unmanaged $(3.0 \pm 0.3)$ than mowed $(1.5 \pm 0.2)$ and growth regulator $(1.5$ $\pm 0.3)$ plots. We observed a total of 30,18 , and 19 bird species on the ground or on plants in the unmanaged, mowed, and growth regulator plots, respectively. Fifteen bird species were observed in the unmanaged plots but not in the managed plots.
Red-winged blackbirds (Agelaius phoeniceus), American robins (Turdus migratorius), American goldfinches (Carduelis tristis), and European starlings (Sturnus vularis) were the birds we most frequently observed $(26.3 \%, 15.7 \%, 11.2 \%$, and $10.5 \%$ of the total individuals seen, respectively) using the study plots.

Species-specific variation occurred in bird use of unmanaged and managed vegetation (Table 2). Red-winged blackbirds, American goldfinches, field sparrows (Spizella pusilla), and song sparrows (Melospiza melodia) used unmanaged vegetation plots more than plots where vegetation management practices (mowing or chemical) were implemented, whereas European starlings and American robins were observed primarily in managed plots.

Mammals. We observed more $(P<0.001)$ white-tailed deer (sunset and FLIR survey combined) in mowed plots $(4.3 \pm 0.5)$ than either unmanaged control $(2.2 \pm 0.6)$ or growth regulator $(1.6 \pm 0.3)$ plots. Overall, we observed more $(P<0.001)$ deer in the plots in July $(4.2 \pm 0.7)$, September $(4.8 \pm 1.3)$, and October $(3.0 \pm 0.5)$ than in May $(0.8 \pm 0.3)$.

We captured a total of 13 small animals from 6 species in the unmanaged plots in April of 2003 (0.5 captures · 100 trap nights $^{-1}$ ) and October of 2003 (1.7 captures · 100 trap nights $^{-1}$ ). We captured no small mammals ( 0.0 captures $\cdot 100$ trap nights ${ }^{-1}$ ) in either the mowed or growth regulator plots.

\section{DISCUSSION}

The plant growth regulator (herbicide mixture) was expected to reduce the growth of cool-season grasses and kill broad-leaved forbs and legumes. Periodic observations of the vegetation within the growth regulator plots showed that the plant growth regulator reduced the growth and suppressed seedhead formation in cool-season grasses (e.g., tall fescue) for 6 to 8 weeks following application. Seedhead suppression and reduced growth of some grasses were likely due to the application 
Table 2. Mean ( \pm SE) no. of birds observed per 5-minute survey of the 9 most frequently observed species in unmanaged, mowed, and growth regulator plots in Erie County, Ohio, May through October 2003.

\begin{tabular}{lccc}
\hline & & No. of birds per 5-minute survey $( \pm \mathrm{SE})$ & Growth regulator \\
\cline { 2 - 4 } \multicolumn{1}{c}{ Species } & Unmanaged & Mowed & $0.19 \pm 0.05 \mathrm{~B}$ \\
\hline Red-winged blackbird & $1.23 \pm 0.23 \mathrm{~A}^{1}$ & $0.16 \pm 0.04 \mathrm{~B}$ & $0.29 \mathrm{~B}$ \\
American robin & $0.03 \pm 0.01 \mathrm{~A}$ & $0.41 \pm 0.09 \mathrm{~B}$ & $0.001 \pm 0.001 \mathrm{~B}$ \\
American goldfinch & $0.64 \pm 0.14 \mathrm{~A}$ & $0.03 \pm 0.02 \mathrm{~B}$ & $0.19 \pm 0.07 \mathrm{~B}$ \\
European starling & $0.01 \pm 0.001 \mathrm{~A}$ & $0.43 \pm 0.12 \mathrm{~B}$ & $0.13 \pm 0.04 \mathrm{~A}$ \\
Eastern kingbird (Tyrannus tyrannus) & $0.13 \pm 0.03 \mathrm{~A}$ & $0.05 \pm 0.03 \mathrm{~A}$ & $0.06 \pm 0.02 \mathrm{~A}$ \\
Eastern meadowlark (Sturnella magna) & $0.13 \pm 0.04 \mathrm{~A}$ & $0.20 \pm 0.06 \mathrm{~A}$ & $0.01 \pm 0.001 \mathrm{~B}$ \\
Field sparrow & $0.22 \pm 0.05 \mathrm{~A}$ & $0.05 \pm 0.02 \mathrm{~B}$ & $0.22 \pm 0.07 \mathrm{~B}$ \\
Brown-headed cowbird (Molothrus ater) & $0.001 \pm 0.001 \mathrm{~A}$ & $0.04 \pm 0.02 \mathrm{~A}$ & $0.0 \pm 0.0 \mathrm{~B}$ \\
Song sparrow & $0.22 \pm 0.05 \mathrm{~A}$ & $0.0 \pm 0.0 \mathrm{~B}$ & \\
\hline
\end{tabular}

${ }^{1}$ Means within the same row with the same letter are not different $(P>0.05)$ according to a Kruskal-Wallis test.

of the imazapic component of the plant growth regulator mixture (Yelverton et al. 2000). However, as the growing season progressed, other grasses that apparently were not affected by the plant growth regulator (e.g., smooth brome [Bromus inermis Leyss.]) continued to grow, causing the overall vegetation height to exceed the prespecified height of $15 \mathrm{~cm}$ and resulting in the plots being mowed. The dicamba and diflufenzopyr components of the plant growth regulator mixture likely reduced forbs and legumes (e.g., clovers, common dandelion [Taraxacum officinale G.H. Weber ex Wiggers]) in growth regulator plots (Grossman et al. 2002; Lym and Deibert 2005).

Although growth regulator plots were mowed 10\% less frequently than mowed plots, this reduction did not offset the cost of herbicides and application. Costs to apply the plant growth regulator were approximately $\$ 92.5 \cdot \mathrm{ha}^{-1}$ or $\$ 1110$ to spray the $4,1.5$-ha plots twice. Costs to mow were $\$ 10$. $\mathrm{ha}^{-1}$ or $\$ 60$ to mow $4,1.5$-ha plots. A $10 \%$ reduction in mowing is equivalent to 2 fewer weeks of mowing, resulting in a \$120 savings. Therefore, spending \$1 110 to apply chemicals did not reduce mowing enough to offset spraying costs but actually cost $\$ 990$ more than the cost of mowing the plots.

Plant community characteristics, such as the density and structure of vegetation, have been shown to influence bird use of grassland areas (Frawley and Best 1991; Norment 2002). Managing vegetation height, either through mowing or applying a growth regulator, resulted in species-specific patterns of bird use that differed from unmanaged plots. American robins and European starlings were observed almost exclusively in managed plots, whereas red-winged blackbirds, American goldfinches, song sparrows, and field sparrows were observed mostly in the unmanaged plots. These birds were likely using the taller, denser vegetation and woody plants in the unmanaged plots (King and Savidge 1995; Warren and Anderson 2005).

Vegetation height management influenced the use of plots by mammals. During our study, we captured small mammals only in the unmanaged plots. Other researchers have reported that mowing vegetation appears to discourage small mammal use of grasslands (Lemen and Clausen 1984; Edge et al. 1995). Approximately twice as many white-tailed deer were observed in the mowed plots than in the unmanaged and growth regulator plots. Broad-leaved herbaceous plants, such as clovers and common dandelion, constitute large portions of deer summer diets (Korschgen et al. 1980; Rose and Harder 1985). The large reductions in forb and legume cover following the growth regulator applications resulted in much less forage available in the regulator plots. Thus, less white-tailed deer use might be due to the reduction in preferred forage plants.

\section{MANAGEMENT IMPLICATIONS}

Managing vegetation height altered plant community characteristics and wildlife use of the study plots. Land managers should use different vegetation height management methods, depending upon their management goals for cool-season grasslands. Reducing wildlife use of cool-season grasslands might be accomplished by intensive mowing and applying a broadleaf-selective herbicide. In contrast, not managing vegetation height in cool-season grasslands should result in more bird and mammal use. However, disturbance of coolseason grasslands through mowing, burning, or grazing every few years will likely be necessary to deter woody plant invasion.

Plant growth regulator application is not a cost-effective alternative to mowing for managing vegetation height in coolseason grasslands that consists of a variety of plant species. Additional research is needed to determine if this method of vegetation height management would be cost-effective in monotypic stands of vegetation that are affected by a plant growth regulator.

\section{LITERATURE CITED}

BolLINGER, E. K. 1995. Successional changes and habitat selection in hayfield bird communities. Auk 112:720-730.

Edge, W. D., J. 0. Wolff, and R. L. Carey. 1995. Density-dependent responses of gray-tailed voles to mowing. Journal of Wildlife Management 59:245-251.

Frawley, B. J., AND L. B. Best. 1991. Effects of mowing on breeding bird abundance and species composition in alfalfa fields. Wildlife Society Bulletin 19:135-142.

Grossman, K., G. Caspar, J. Kwiatkowski, and S. J. Bowe. 2002. On the mechanism of selectivity of the corn herbicide BAS $662 \mathrm{H}$ : a combination of the novel auxin 
transport inhibitor diflufenzopyr and the auxin herbicide dicamba. Pest Management Science 58:1002-1014.

KING, J. W., AND J. A. SAVIDGE. 1995. Effects of the conservation reserve program on wildlife in southeast Nebraska. Wildlife Society Bulletin 23:377-385.

Korschgen, L. J., W. R. Porath, and O. Torgerson. 1980. Spring and summer foods of deer in the Missouri Ozarks. Journal of Wildlife Management 44:89-97.

Lemen, C. A., and M. K. Clausen. 1984. The effect of mowing on the rodent community of a native tall grass prairie in eastern Nebraska. Prairie Naturalist 16:5-10.

LYM, R. G., AND K. J. DeIBERT. 2005. Diflufenzopyr influences leafy spurge (Euphorbia esula) and Canada thistle (Cirsium arvense) control by herbicides. Weed Technology 19:329-341.

MorRé, D. J. 1993. A 10-year evaluation of plant growth regulator carryover in roadside test plots in Indiana. Journal of Plant Growth Regulation 12:91-93.

Nelson, L., JR., AND F. W. Clark. 1973. Correction for sprung traps in catch/effort calculations of trapping results. Journal of Mammalogy 54:295-298.

Norment, C. J. 2002. On grassland bird conservation in the northeast. Auk 119:271-279.

Reynolds, J. H., W. A. Krueger, C. L. Walker, and J. C. Waller. 1993. Plant-growth regulator effects on growth and forage quality in tall fescue. Agronomy Journal 85:545-548.

Robbins, R. A., N. H. Martin, and S. T. Prebonick. 2002. Soil survey of Erie County, Ohio. Washington, DC: USDA, Natural Resources Conservation Service. 354 p.
Robel, R. J., J. N. Briggs, A. D. Dayton, and L. C. Hulbert. 1970. Relationship between visual obstruction measurements and weight of grassland vegetation. Journal of Range Management 23:295-297.

Rose, J., AND J. D. Harder. 1985. Seasonal feeding habits of an enclosed high density white-tailed deer herd in northern Ohio. Ohio Journal of Science 85:184-190.

Seamans, T. W., S. C. Barras, G. E. Bernhardt, B. F. Blackwell, and J. D. Cepek. 2007. Comparison of two vegetation management practices for wildlife control. Human-wildlife Conflicts 1:97-105.

Vickery, P. D., AND P. W. Dunwiddie. 1997. Grasslands of northeastern North America: ecology and conservation of native and agricultural landscapes. Lincoln, MA: Massachusetts Audubon Society. 297 p.

Warren, K. A., and J. T. Anderson. 2005. Grassland songbird nest-site selection and response to mowing in West Virginia. Wildlife Society Bulletin 33: 285-292.

Washburn, B. E., T. G. Barnes, C. C. Rhoades, and R. Remington. 2002. Using imazapic and prescribed fire to enhance native warm-season grasslands in Kentucky, USA. Natural Areas Journal 22:20-27.

Yelverton, F. H., J. D. Hinton, and T. W. Gannon. 2000. Imazapic for tall fescue (Festuca arundinacea) seedhead suppression. Proceedings of the Southern Weed Science Society 53:130.

ZaR, J. H. 1996. Biostatistical analysis. 3rd ed. Upper Saddle River, NJ: PrenticeHall. $662 \mathrm{p}$. 